INTERNATIONAL TRADE IN SERVICES: MORE THAN MEETS THE EYE

\author{
Lawrence J. White \\ Stern School of Business \\ New York University \\ e-mail: lwhite@stern.nyu.edu
}

\author{
Forthcoming in \\ Trade, Laws, and Institutions \\ James C. Hartigan, ed. \\ Blackwell Publishers
}

\author{
Draft: $2 / 28 / 02$ \\ Please do not quote or cite \\ without the permission of the author \\ Comments welcomed
}

\begin{abstract}
In this paper I present an overview of international trade in financial services. Though often intangible and "invisible", trade in services is important, accounting for almost a fifth of total world trade in 2000; and trade in services has been growing in both absolute and relative terms, though growth was more rapid in the 1980s than in the 1990s. The international negotiating framework for reducing barriers to trade in services -- the General Agreement on Trade in Services (GATS) -came into existence in 1995, as part of the World Trade Organization (WTO). The GATS has thus far had only limited success in achieving reductions in barriers to trade in services, though a negotiating round among member countries is currently under way. This slow progress is largely due to the extensive national regulation that frequently surrounds services and the entry (and trade) barriers that are often part of that regulation. The structure of the GATS document itself, as well as the WTO's post-Seattle defensiveness, reflects the political sensitivity of these national regulatory issues; but this sensitivity, unfortunately, has impeded progress in reducing trade barriers.
\end{abstract}




\title{
INTERNATIONAL TRADE IN SERVICES: MORE THAN MEETS THE EYE
}

\author{
Lawrence J. White ${ }^{*}$ \\ Stern School of Business \\ New York University \\ e-mail: lwhite@stern.nyu.edu
}

\section{Introduction}

The common image of international trade is that of goods -- sacks of grain, rolls of steel, pallets of machinery -- traveling across borders by boat, rail, or truck. Though this image does represent the dominant form of trade, it nevertheless leaves out another significant, and growing, form of trade: international trade in services.

Traditionally, services have generally been considered to be inherently non-tradable -- or at least difficult to trade. There were acknowledged to be exceptions, such as tourism or the transportation and other services that attached to the trade in goods. Still, trade in services seemed almost to be an oxymoron.

This is no longer the case. With the expansion of serviges as a proportion of national output for many economies, and especially for developed economies, ${ }^{1}$ there has also come an expansion of international trade in services and an expanded recognition of and interest in that trade. Among the indications of that expanded interest and concern are the establishment within the World Trade

\footnotetext{
* I would like to thank Gary Hufbauer and James Hartigan for valuable comments on an earlier draft.

${ }^{1}$ See Kang (2000b) for recent cross-country data that show the generally rising proportion of services in GDP over time and across higher-income countries.
} 
Organization (WTO) of a General Agreement on Trade in Services (GATS)that roughly parallels the General Agreement on Tariffs and Trade (GATT), with active negotiations among the 144 WTO members and a Council Trade in Services to administer it; an annual report by the U.S. International Trade Commission (USITC), Recent Trends in U.f. Services Trade; and a growing pile of statistics, academic studies, and monographs on the topic. ${ }^{2}$

This paper will be about the growing importance of international trade in services. In Section II we will highlight the dissimilarities, as well as the similarities, between trade in services and trade in goods. In Section III we will present recent data that highlight the absolute and relative growth of international trade in services. Section IV will provide an overview of the multilateral trade negotiations that have occurred with respect to services. And Section V will provide a brief conclusion.

\footnotetext{
${ }^{2}$ A complete bibliography is beyond the scope of this paper. A fairly comprehensive list of papers and books, with links, can be found at <http://www.SITrends.com>, a web site maintained by the Mark Twain Institute. Especially informative anthologies include Aharoni (1997), Aharoni and Nachum (2000), Claessens and Jansen (2000), Findlay and Warren (2000), Stephenson (2000), Sauve and Stern (2000), and Stern 2001).
} 


\section{The Dissimilarities, and Similarities, between Trade in Goods and Trade in Services}

\section{A. The dissimilarities.}

International trade in goods is easy to visualize. The goods are tangible. They physically move from one geographical location to another across a border -- by ship, rail, or truck. So long as the geographic exit and entry points of the goods are well specified, the reporting, documentation, classification, taxation (if any), and data-gathering that pertain to the goods shipments are relatively straightforward. ${ }^{3}$

Further, even the barriers to trade in goods are relatively easy to visualize and understand. A tariff is a tax on the import of a good. A quota is a quantitative limitation on the import of a good. Even the more subtle regulatory restrictions on goods imports, such as customs delays at borders or "safety"-motivated restrictions, are easy to understand.

Services are different, in at least two important respects. First, they are usually intangible; they cannot be seen, held, smelled, or touched; they also cannot be stored. They usually do not cross international borders the way goods do. Second, they are often regulated by governmental entities. Both of these differences make trade in services different from trade in goods and help explain why trade in services was considered relatively unimportant and why the liberalization of trade in services has proceeded much more slowly than has been true for trade in goods.

1. Intangibility. The intangibility of services means that their trade cannot occur in the same, physical-shipment way that trade in goods occurs. In an important sense, they are invisible. Indeed, international services remittances are often described as part of the "invisibles" in the discussion of a country's balance of payments.

International trade in services can occur in one of four ways or "modes": 4

\footnotetext{
${ }^{3}$ Smuggling, of course, is an exception.

${ }^{4}$ These modes are specified in Article I of the GATS.
} 
(a) Cross-border. Some services do actually originate with a provider in one country and "move" across a border to a user-recipient in another country. Some examples include:

-- The sale of electricity from one country to another;

-- Telephone communications across borders;

-- Catalog- or Internet-based retail transactions across borders;

-- The transportation services that attach to goods movements in international trade;

-- The provision of a loan, deposit, insurance, or other financial services product across a border;

-- Distance learning: a student located in one country taking a course offered electronically by an educational institution located in another country.

Even in these instances, the "movement" is invisible and instantaneous; the service does not stop and wait at the border while a customs official inspects, classifies, and records it and determines the appropriate tariff.

(b) Consumption abroad. Some services are consumed through the travel of the customer from one country to the provider in another country. Examples include

-- Tourism;

-- Study (education) abroad;

-- Medical treatment abroad.

Though a country's nationals who have traveled abroad may be stopped at the border upon their return and asked what goods they have bought abroad (and appropriate tariffs levied), they are rarely (if ever) asked what services they have bought and consumed.

(c) Commercial presence. For many services, the most effective delivery mechanism is often the establishment of a physical presence (a branch office or subsidiary) in the country in which the service is to be sold and consumed. Underlying the desirability of the physical presence abroad are at least two phenomena: First, the individual units of the service are not sufficiently 
valuable so as to warrant the customers' traveling abroad for them (many people may be willing to travel 5 miles for a restaurant meal, but few are willing to travel 5,000 miles solely for a restaurant meal); and second, the transportation and scale economies of provision argue for bringing the physical establishment and its service into proximity with the customers (rather than having them all travel abroad to obtain the service). Further, a local presence will be more desirable when local knowledge of the customers is especially important for the seller (e.g., banks want to have a considerable amount of information about the creditworthiness of their borrowers); when the customers want first-hand contact with or convenience related to the sellers (e.g., depositors want to be able to have ready access to their funds and/or to interact with tellers; retail merchandise customers want to be able to see the items that they are buying, perhaps sample them or try them on); and/or when continuing physical contact between provider and customer is necessary (e.g., for some professional services short visits supplemented by telephonic contact may not be sufficient).

Consequently, commercial presence abroad is a common phenomenon for (among others):

-- Banks and other financial services providers;

-- Restaurant chains;

-- Hotel chains;

-- Retail merchandise chains;

-- Accountancy branches;

-- Law offices branches.

Commercial presence is, of course, also important for many categories of goods, where branch/affiliate factories are alternatives to direct shipments. But for goods, direct shipments from the home country are often a fairly close substitute for production abroad. By contrast, direct "shipment" is likely to be an exceedingly poor substitute for the commercial presence mode of delivering many services. ${ }^{5}$

5 There is, of course, the question of whether the commercial presence abroad should be 
(d) Temporary presence (presence of natural persons). A service may be delivered through the temporary presence abroad of an individual or group of individuals who deliver the service while abroad. Examples include:

-- Visiting entertainers (e.g., orchestras, theater companies, rock stars);

-- Temporary consultancies;

-- Short-term construction projects.

Some services may be capable of being delivered through more than one mode.

Since the commercial presence method is a common form of delivery, it is worth additional attention. Commercial presence abroad will mean the necessity for investment (foreign direct investment, or FDI) in the host country from the provider in the home country. Also, personnel from the provider enterprise headquarters will have to travel to the location abroad to deliver services, hire personnel, and supervise the personnel. This necessity for investment in and travel to the host country in order effectively to deliver the services means that the delivery process is more complex than is true for the simple shipment of goods across a border. In turn, the complexity of delivery provides greater and more subtle opportunities for host country governments to impede the delivery of those services from abroad (and thus favor domestic providers). Restrictions on inbound FDI (including restrictions on ownership structures and arrangements), restrictions on immigration, and restrictions on commercial location and establishment can seriously impede international trade in services.

For example, White's (2001) examination of international trade in accounting services

operated through a directly owned subsidiary or branch, or whether instead a licensing or franchising arrangement with an overseas partner should be arranged. This question applies equally strongly to goods or services. How it is resolved is dependent partly on the regulatory issues that are discussed below and partly on the nature of the product or service, the managerial capabilities of the provider, the contractual and monitoring possibilities, etc. It is worth noting that the GATS directly deals with issues related to commercial presence, whereas the GATT does not. 
found the following types of restrictions present in one or more countries:

-- Nationality requirements with respect to who can offer local accounting services;

-- Residence or establishment requirements;

-- Restrictions on the international mobility of accounting personnel;

-- Restrictions as to the use of the brand names of firms or requirements that only local names be used;

-- Restrictions on advertising or other promotional efforts; restrictions on price competition;

-- Quantitative limits on the provision of services;

-- Restrictions on the services that accounting firms can and cannot provide;

-- Restrictions on who can be an owner of an accounting firm; e.g., requirements that all or a specified number or fraction of the owners of an accounting firm be local citizens; be residents; be active in the business of the firm; be locally-licensed; be members of an approved professional organization;

-- Restrictions as to the legal form or structure that an accounting firm must have (e.g., prohibitions on a corporate form);

-- Discriminatory arrangements with respect to the licensing of foreign accountants, including applications, testing, assessments of educational qualifications, relevant experience;

-- Differential taxation treatment;

-- Restrictions on international payments for services;

-- Restrictions on cross-border flows of information;

-- Inadequate protections for the intellectual property related to accounting services, such as computer software;

-- "Buy national" practices of governments with respect to their purchases of accounting services. 
These types of regulatory restrictions on trade are found generally across the services sector. ${ }^{6}$

This last discussion provides a convenient segue to the second distinctive feature of services.

2. Regulation. Services are often subject to extensive regulation by governments. As an example, consider the list of specific industries in the U.S. that were usually described as "heavily regulated" in the 1960s and 1970s and that were the targets of substantial deregulation or regulatory reform efforts in the U.S. during the last quarter of the twentieth century (Joskow and Rose 1989; Noll 1989; Winston 1993; Joskow and Noll 1994):

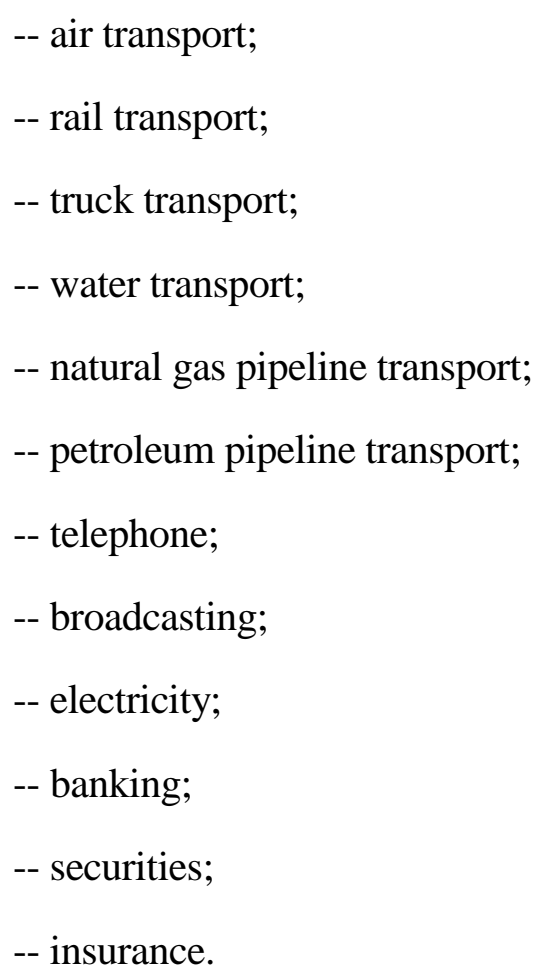

All of these industries are services. Also, though the list was drawn from the U.S. experience, similar lists of industries in the 1960s and 1970s in other countries were either heavily regulated or under government ownership and have subsequently been subject to deregulation or privatization.

\footnotetext{
${ }^{6}$ See, for example, Hoekman and Braga (1997) and the essays in Aharoni (1997) and Findlay and Warren (2000).
} 
Another broad category of services -- professional services, such as those provided by doctors and other health care providers, lawyers, accountants, architects -- are also subject to direct or indirect government regulation. Sometimes a governmental body directly regulates the profession; sometimes that regulation is delegated to a professional association, with the government retaining oversight.

This regulation adds yet another layer of complexity to international trade in services and to efforts to liberalize this trade. Regardless of form, regulation is almost always justified as governmental activity that is being pursued so as to advance "the public interest". Ideally, this pursuit of "the public interest" would involve government efforts to address market failures: specifically, the presence of significant market power (addressed through "economic" regulation, such as price limitations); the presence of significant externalities or spillover effects (addressed through health-safety-environment regulation, involving changes in production processes or product/service design); and/or the presence of significant asymmetric information problems (addressed through information regulation, involving required information attached to goods or services; see Joskow and Rose 1989; Gruenspecht and Lave 1989; White 1996). In addition, it is clear that governments often use regulation for outright "consumer protection", exercising paternalistic actions, and also use it in attempts to redistribute income.

Even good regulatory intentions can go awry, however, and regulatory bodies and procedures can be "captured" by groups -- often producers -- that care strongly about favorable outcomes for themselves; or the regulatory process may have begun as a regulatory capture effort. With capture usually comes protection: regulatory barriers to entry that favor incumbents. Among the entrants that are shut out are potential entrants from abroad. And thus regulation creates and maintains barriers to international trade in services.

The regulatory structure and procedures themselves add to the complexity of liberalizing trade. The regulatory process is imbued with a "protect the public interest" or outright "consumer 
protection" ethos. Incumbents can argue to government regulatory officials that it is the incumbents that are the embodiment of that public interest and that entry -- especially entry from abroad, by "foreign" entities that (arguably) may care less about the domestic public interest and that are inherently harder to regulate -- would undermine or weaken the regulation and would thus be antithetical to the public interest. And there are usually rules and laws that must be rescinded or modified to permit entry, giving incumbents ample oppoftunity to make their case and delay or impede entry. Again, international trade in services suffers. ${ }^{7}$

We will return to these issues in Section IV when we discuss the trade negotiations that have occurred in the services area.

\section{B. Similarities.}

Though, as the previous section argued, trade in goods and trade in services exhibit substantial dissimilarities, they also exhibit a fundamental similarity: The opening, and expansion, of international trade in services can bring the same type of economic gains to countries -- an improved allocation of resources and higher living standards -- as is brought by trade in goods. Trade allows a country to focus its resources on what it does relatively well, importing the goods and services that it does less well and paying for those imports with the export of the goods and services that it does especially well. At its heart, the argument for the benefits of trade, whether for services or goods, is fumdamentally an argument for the benefits of competition, applied in an international framework. ${ }^{8}$

${ }^{7}$ However, where a significant market imperfection is present (and has motivated domestic regulation), then the theory of "second-best" tells us that the amelioration of another market imperfection (e.g., a reduction in trade barriers) will not necessarily improve welfare; see Lipsey and Lancaster (1956-57).

8 A more detailed analytical framework to support this position, along with analyses of exceptions and caveats, can be found in any international economics text; see, for example, Yarbrough and Yarbrough (1997) or Pugel and Lindert (2000). 
This standard advantages-of-trade argument is based on reallocations of resources with given or static technologies. An additional "kick" to expanded output may be provided by the improved technologies and new ideas that accompany the expanded goods and services from abroad. The commercial presence/physical establishment that is important for many services may be an especially fortuitous vehicle for the introduction and transmission of these new ideas.

Further, just as expanded trade in goods that are important inputs into the production of other goods can have a multiplicative effect in reducing "downstream" distortions, improving resource allocations, and encouraging further trade flows, so too can expanded trade in crucial input services have multiplicative effects. As Deardorff (2000) points out, services such as freight transportation, telecommunications, finance, and law are all important inputs into the flow of goods in international trade. Greater efficiency in the provision of these services, brought about by expanded trade in these services, should encourage expanded goods trade. Also, financial services, accounting services, and legal services are all essential inputs into commercial transactions in any economy. Again, greater efficiency in the provision of these services, brought about by expanded trade, should encourage greater efficiency throughout an economy.

Over the past decade an important empirical literature has supported these latter notions (e.g., King and Levine 1993a, 1993b; Levine 1996, 1997, 1998, 1999; Levine and Zervos 1998; La Porta et al., 1997, 1998; Rajan and Zingales 1998; Beck et al. 2000). The evidence clearly shows that greater development of a country's financial sector and of the laws and rules that surround financial and commercial transactions have significant positive influences on that country's rate of economic growth. Further, greater involvement of foreign financial firms in a country's financial services sector tends to encourage greater development of that sector and thus encourage more rapid economic growth (Levine 1996; Claessens et al. 2000; Claessens and Jansen 2000). Also, as White (2001) suggests, greater involvement of the major (worldwide) accounting firms in Asian economies in the 1990s could well have led to more rigorous accounting standards in those 
countries and an amelioration of the financial crises that beset the region in the late 1990s.

In sum, trade is generally beneficial; and, in that respect, the distinct characteristics of trade in services may well reinforce this general message. 


\section{The Expansion of Trade in Services: Predictions and the Data}

In the Introduction we mentioned the growing importance of international trade in services. In this section we will document that claim.

\section{A. Why would we expect trade in services to be growing?}

There are at least four reasons why we would expect to see a rising trend in international trade in services -- rising in absolute terms, rising relative to world GDP, and rising relative to trade in goods.

First, services appear generally to have an income elasticity of demand that is substantially greater than one, especially in developed economies (Kang 2000). As countries grow, they tend to produce and consume more-than-proportionately greater levels of services. Accordingly, to the extent that any services can cross borders, we would expect generally to see the growth of these cross-border services as well, and they would be documented as a growth in international trade in services.

Second, the technologies that underlie important categories of services have experienced rapid improvements in the past few decades. Included in this list are telecommunications engineering, data processing, transportation engineering, and biological sciences. The consequences for services have been profound. Better quality services, with greater variations and qualities, can be offered by more firms at lower costs over greater distances, generating more effective competition among pfpviders. The real (quality-adjusted and inflation-adjusted) prices of many services have decreased. ${ }^{9}$ The heightened quality/variety with lower prices has reinforced the

\footnotetext{
9 This decrease is in contradiction to the predictions of Baumol (1967). But the Baumol predictions were based on a very limiting set of assumptions about the nature of the production and consumption of services.
} 
income-elasticity effects to encourage greater consumption of services. And, again, some of this should spill over to international trade in services.

Third, the technological improvements in telecommunications, data processing, and transportation have had a direct beneficial effect on those services that are delivered internationally through the cross-border mode and an indirect beneficial effect on other services that are delivered through the other three modes. Further, because these improved technologies allow senior managers better to manage multiple-establishment enterprises that are located at geographically separated locations, they directly benefit the delivery of services that occur through the commercial presence mode.

Finally, to the extent that governments have eased their barriers to trade in services, that too would encourage greater trade.

In sum, there are strong reasons to predict a rise in the importance of international trade in services. We now turn to the data.

\section{B. The data and what they show.}

There are three categories of data on international trade in services that will be presented: (1) world data, including major regions; (2) U.S. data; and (3) U.S. data on sales of services from overseas establishments.

1. World trade data. World data on trade for 2000 can be found in WTO (2001a) and at the WTO's website <http://www.wto.org>. The services data cover all "commercial services"; i.e., all services except non-commercial services provided by governments (but commercial services provided by, say, a government airline would be included). However, the level of detail and extent of coverage for services are far less than are provided for goods; this statistical neglect is an indication of the general neglect -- until recently -- of attention to services: in national income accounts and balance of payments statistics, as well as in the multilateral negotiation arena. 
The data for trade in services cover only cross-border, consumption abroad, and temporarypresence forms of trade. The commercial presence form is not covered.

Table 1 provides data for trade in goods and in services in 2000, as well as average annual percentage increases since 1980. As can be seen, services trade constituted somewhat less than a fifth of total world trade in 2000. Since 1980, trade in services has expanded appreciably faster than trade in goods; but most of that relative expansion took place during the 1980s; since 1990 trade in services has grown only slightly faster than trade in goods. To this author's knowledge the reasons for this slowdewn in the relative growth of trade in services in the 1990s have not been explored or explained. ${ }^{10}$ However, it is noteworthy that the decade of rapid growth in services trade, the 1980s, was also the decade that saw the Uruguay Round propel services trade to a prominent place in the multilateral negotiating arena.

Both trade series are value-based measures. For trade in goods, a volume-based measure (which controls for price changes) is available as well, but no such measure is available for trade in services. Table 1 shows the rates of growth of real (constant-price) world GDP and the volume of goods trade for these same decades. The (real) volume of goods traded grew appreciably faster than real world GDP, especially for the 1990s. Although it seems likely that real services trade also exceeded real GDP growth, that claim must (unfortunately) remain a supposition until better data are available.

Table 2 presents the trade data classified by major regions. ${ }^{11}$ Trade in services constituted over a fifth of total exports in 2000 for North America and for Western Europe and over a fifth of

${ }^{10}$ It may be the case that these observed trade flows -- which represent the cross-border, consumption-abroad, and temporary-presence modes -- are being supplanted by the commercialpresence mode. This is only a hypothesis, however, which should be examined in future research.

11 The WTO (2001a) does not present services data aggregations for Eastern Europe and for the Middle East, although trade in goods aggregates were presented. This is another indicator of the lack of attention to services and to trade in services that has prevailed until recently. 
total imports for Western Europe and Africa. The worldwide slowdown in the relative growth of services trade in the 1990s was clearly due to the slower growth rates for services exports and imports in the 1990s for North America, Western Europe and Asia. The slower growth of services trade in North America in the 1990s is especially striking.

Table 3 shows the ten leading country exporters and importers for goods and for services in 2000. The U.S. was the leading trader in all four categories; the U.S.'s services exports accounted for almost a fifth (19.16\%) of the world trade in services, and the U.S.'s goods imports accounted for over a fifth $(20.34 \%)$ of the world's trade in services. The U.S. share in both categories was more than double the share of the runner-up country. The aggregated share of the leading ten traders for each of the four categories of trade were quite similar. And the leading trader countries tended to be dominant in all four categories: Only twelve countries were needed to account for the 40 (top $10 \times$ 4) leading positions in the four categories, and seven countries (the U.S., the U.K., Japan, Germany, France, Italy, and the Netherlands) appeared on all four lists.

Table 4 provides the three major categories of trade in services; no finer classifications are available on a worldwide basis. Transportation services (passenger and freight transportation and seaport/airport charges) accounted for $23 \%$ of world trade in services; travel services (tourism) accounted for $32 \%$ of the world total; and other services (everything else) accounted for $45 \%$ of the world total. The U.S. was the leading exporter and importer in all three categories. The aggregated share of the leading ten trading countries in each category showed substantially greater variation than was true for Table 3. But, as was true for the broad goods and services trade categories, the leading countries in the specific services trade categories tended again to be dominant in all categories: only 16 countries were needed to account for the 60 (top 10 x 6) leading positions in the six categories, and four countries (the U.S., the U.K., Germany, and France) appeared on all six lists.

2. U.S. services trade data. Substantially finer detailed data are available for U.S. trade in 
services, as is shown in Table 5. ${ }^{12}$ In aggregate, the U.S. was a substantial net exporter of services in 2000; this net export surplus position has been true since at least 1970 (Landefeld and Young 1988; WTO 2001). The U.S.'s comparative advantage varied within the services sector, however, and the U.S. was a significant net importer of some services: passenger and other (freight) transportation, insurance, telecommunications, and miscellaneous disbursements.

3. U.S. affiliates data. As was discussed above, services are often best provided through a commercial (physical) presence of a branch, subsidiary, or affiliate. The data presented thus far for the lorld and for the U.S. do not capture such-services sales. They are available, however, for the U.S. ${ }^{13}$ Table 6 provides these data for $1999 ;{ }^{14}$ Table 7 provides the annual aggregates for 19861999.

The data in these tables indicate that the U.S. was a net exporter of services provided through these sales in 1999 and has been a net exporter in every year since 1987, the first year for which these data are available. ${ }^{15}$ The U.S.'s strongest comparative advantage has been in the following industrial categories: motion picture and sound recording; broadcasting and telecommunications; information and data processing; finance, except depositary institutions; computer design and related services; other professional, scientific, and technical services; utilities; administration support and waste management; and accommodation and food services.

4. A summing up. The data show that services constitute a substantial fraction of the world

12 Additional data and information can be found in USITC (2001).

${ }^{13}$ The data in Tables 6 and 7 do not cover sales by bank affiliates, apparently because banks were not included in the surveys that were conducted to generate the data (Borga and Mann 2001).

14 This is the most recent year available; the affiliates sales data appears consistently to lag the services trade flows data by a year.

${ }^{15}$ Landefeld and Young (1988) provide earlier data that show net surpluses extending back to at least 1977. 
trade total and that this fraction has been growing; this relative growth was especially robust in the 1980s. The U.S. has been and continues to be a net exporter of services, measured both as direct flows and as sales through affiliates. It is not surprising that the U.S. has generally been an ardent advocate of reduced barriers to international trade in services. ${ }^{16}$

${ }^{16}$ The U.S. has, however, been selective in its advocacy and in its openness. Though the U.S. has relatively low barriers with respect to financial services and especially banking (McGuire and Schuele 2000; Skipper 2001; White 2002) and telecommunications (Warren 2000a, 2000b; Warren and Findlay 2000), the U.S. has high barriers with respect to maritime shipping services (White 1988; Fox and White 1995; Kang 2000a; Kang and Warren 2000), to domestic air service (Kasper 1988), and even to accountancy services (Colecchia 2000). for example, U.S. citizen ownership requirements for the provision of coastal maritime shipping services (and U.S. citizenship for staffing as well), domestic air services, and over-the-air broadcasting and telephony constitute absolute barriers to entry. 


\section{Multilateral Trade Negotiations with Respect to International Trade in Services}

\section{A. Background. ${ }^{17}$}

Through the mid 1970s there was no widespread perception that trade in services was a significant enough phenomenon to warrant multilateral attention that was comparable to the attention that had been focused on trade in goods since the 1940s through the GATT. Beginning in the late 1970s, however, the U.S. began actively pursuing bilateral "open-skies" agreements to reduce the impediments that U.S. airlines faced abroad; and the U.S. also was increasingly concerned about how other countries were treating the overseas branches of U.S. banks, securities firms, and a few other services providers. Further, the European Common Market was recognizing that services flows among its member countries was a major task to tackle. During the early 1980s the U.S. began a more concerted diplomatic effort to bring trade in services into the realm of multinational negotiation and bargaining.

During the "Uruguay Round" of GATT negotiations of the late 1980s and early 1990s, there was a more general international realization that trade in services needed to be brought into the formal multilateral negotiating arena. ${ }^{18}$ The eventual result was the creation of the World Trade Organization (WTO) as a successor to the organization that had administered the GATT, the negotiation of a general agreement on services -- the GATS -- and the parallel placement of the GATT and the GATS within the WTO. ${ }^{19}$ The GATS came into effect on January $1,1995$.

\footnotetext{
${ }^{17}$ A more extensive treatment of the diplomatic history of the GATS can be found in Nicolaidis (1989).

18 Also, the 1988 international agreement among bank supervisory agencies (the "Basel Accord") on minimum capital requirements for banks was, in essence, an agreement to restrict the national levels of subsidies for banks (White 1996).

19 An "Agreement on Trade-Related Aspects of Intellectual Property Rights" (TRIPS) was also reached in the Uruguay Round and included in the WTO, with a separate council to administer it.
} 


\section{B. The GATS. ${ }^{20}$}

The GATS is a broad and expansive document that applies to all of the 144 (as of early 2002) country members of the WTO and that applies to virtually all services. The two exceptions are government services that are of a non-commercial nature (e.g., social insurance, public safety, national defense) and air traffic rights (which are reserved for separate bilateral negotiations). ${ }^{21}$ It is a broad set of principles that has the goal of encouraging freer trade in services. The GATS establishes general commitments toward most-favored-nation (MFN) treatment, transparency in domestic regulation of services, market access, and national treatment of services suppliers. It encompasses the commercial-presence mode of delivery, as well as the cross-border, consumptionabroad, and temporary-presence modes. A Council for Trade in Services, composed of all WTO (GATS) members, administers the GATS.

Unfortunately, as will be discussed below, the GATS is riddled with loopholes and exceptions -- a formal recognition of the sensitivities and difficulties that come with services in general and the regulatory processes that surround many services. The most important loophole is that a country can choose which of its services sectors, through which mode, will be subject to which of the specific provisions of the GATS. It does so through a specific list of "bindings" (commitments) that apply only to specifically named sectors and modes on a schedule of commitments. It can list as many or as few sectors as it chooses, with as many or as few adherences to the GATS provisions for each sector as it wishes. ${ }^{22}$

${ }^{20}$ More detailed descriptions of the GATS can be found in, e.g., WTO (1999b, 2001d) and Feketekuty (2000a, 2000b).

21 However, aircraft repair and maintenance services, air transport marketing services, and computer-reservations systems are covered.

22 This is commonly described (somewhat perversely) as a "positive list" arrangement, as compared to the "negative list" arrangement that applies to goods, whereby only when a country 
The GATS is encompassed within a set of 29 articles. The following are the major articles and their important features:

-- Article I describes the four major modes of trade in service that were discussed above: cross-border; consumption abroad; commercial presence; and temporary presence (presence of natural persons).

-- Article II establishes a general obligation for most-favored-nation (MFN) treatment. But a country can specifically choose to exempt any sector from MFN treatment, and Article V specifically exempts members of formal multi-country economic-integration areas (such as the European Union, the North American Free Trade Agreement, or Mercosur) from MFN obligations. Also, Article VII (which encourages mutual recognition of qualifications) does not require MFN treatment.

-- Article III establishes a general obligation for transparency with respect to laws, regulations, administrative guidelines, and similar measures that are relevant to trade in services. The transparency should include opportunities for inquiry and notification of significant change.

-- Article V permits countries to participate in regional economic-integration arrangements.

-- Article VI applies to domestic regulation and requires members to ensure that qualification requirements and procedures, technical standards, and licensing requirements do not constitute unnecessary barriers to trade. Domestic regulatory requirements should be based on objective and transparent criteria, such as competence and the ability to provide the service; should not be more burdensome than is necessary to ensure the quality of the service; and, with respect to licensing procedures, should not in themselves be a restriction on the supply of the service. Members must provide an objective and impartial means of reviewing and providing appropriate

lists a goods category and specific restrictions do the presumptions of free trade in the GATT not apply. But the GATS lists also have a "negative list" aspect: When a country does bind itself with respect to a specific service category and mode, it then is committed to the GATS obligations with respect to that service and mode, unless it specifically exempts a GATS provision. 
remedies for administrative decisions that affect trade in services. In addition, when a country has made a binding with respect to a service, measures that affect trade in that service should be administered in a reasonable, objective, and impartial fashion; also, member countries should provide adequate procedures for the mutual recognition of the competence of the providers of other member countries.

-- Article VII encourages mutual recognition of the qualifications of services providers. Member recognition should not constitute a means of discrimination among countries in standards or criteria. Multilateral processes are encouraged.

-- Article VIII addresses domestic services provided by monopolies and restricts the ability of the monopoly providers to interfere with international trade in ways that are inconsistent with the other provisions of the GATS.

-- Article XIII exempts government procłrament from the general GATS obligation, while requiring further negotiations that began in $1997 .^{23}$

-- Article XIV permits exceptions where important national goals, such as public safety and national security, are involved.

-- Article XVI applies to market access by countries that have made a binding with respect to a service. The article prohibits specific limitations (such as quotas) on the number of suppliers, the total value of service transactions or assets, the total number of service operations or quantity of service output, the total number of people employed, the types of legal entity or joint venture through which the service is supplied, and the participation of foreign capital.

-- Article XVII applies to market access by countries that have made a binding with respect to a service. The article requires "national treatment" of service suppliers: Countries should accord

${ }^{23}$ A separate "Government Procurement Agreement" (GPA) applies to the GATT and the GATS but is voluntary. Its goal is MFN, national treatment, and transparency in procurement. See Evenett and Hoekman (2000) for further discussion). 
to foreign services and service suppliers treatment that is no less favorable than is applied to domestic services and suppliers. Specific treatment can be different, so long as the resultant conditions of competition do not favor domestic services or service suppliers.

\section{An assessment.}

Despite almost 20 years of attention, actual efforts at liberalization of trade in services are still in their infancy, and actual results have thus far been modest.

The signing of the GATS by the members of the WTO brought it into effect in 1995 . With the establishment of the GATS came: (1) the submission of schedules by member countries as to the specific services sectors that they were prepared to commit (bind) to GATS-based liberalization rules; (2) further negotiations with respect to more specific guidelines for telecommunications, financial services, marine transportation, and movement of persons; (3) the development of detailed rules (disciplines) for accounting services; and (4) a commitment to begin specific negotiations for widespread services liberalization in 2000. We will address each in turn.

1. Submission of schedules. The submission of schedules by member countries in 1995 did not yield much that was new or newly liberalized. Most countries simply bound themselves to the status quo with respect to the state of their services sector; some countries even bound themselves to less openness than their status quo, so as to give themselves more flexibility for subsequent negotiations and bargaining. Developed countries' bindings tended toward greater degrees of openness; developing countries' bindings tended toward less openness (USITC 1996a, 1996b, 1997, 1998; Altinger and Enders 1996; Hoekman and Braga 1997; WTO 1999a; Hoekman 2000).

Since any binding became a GATS/WTO commitment, which would give a country's trading partners the right of retaliation in the event that the country subsequently tightened its restrictions, the bindings were largely a "standstill" agreement that froze the status quo (or a little less) and discouraged backsliding. In that sense the bindings represented some "progress". 
2. Sector negotiations. Sector negotiations for telecommunications and for financial services concluded in 1997, yielding further specific agreements and more openness-oriented bindings in these two areas, which became annexes to the GATS. ${ }^{24}$ Negotiations for maritime transport services and movements of natural persons also concluded in 1997, but with no agreement.

3. The accounting disciplines. Accounting services was selected by the Council for Trade in Services as a lead sector among professional services (which also encompass doctors, lawyers, architects, etc.) for developing greater specificity for the general principles of the GATS (Ascher 1999; White 2001). This selection was not by chance. Accounting was already a field with a substantial level of international activity. All of the major accounting firms had had wellestablished international branch offices and affiliates. But it was (and continues to be) also a field with substantial domestic regulation in virtually every country and major impediments to trade (Colecchia 2001; White 2001), as the examples described in Section II indicated.

In May 1997 the Council adopted nonbinding guidelines for mutual recognition agreements (MRAs), that amplify the framework of Article VII of the GATS. And in December 1998 the Council adopted disciplines (rules) on the domestic regulation of accountancy that amplify the provisions of Article IV of the GATS, so as to provide greater detail as to transparency, licensing requirements and procedures, qualification requirements and procedures, and technical standards. The disciplines will not come into force, however, until the conclusion of the round of services negotiations that began in 2000 .

4. The GATS 2000 negotiating round. As part of the GATS, member countries agreed to start a round of detailed negotiations with respect to services in 2000. Those negotiations began in 2000, and, as of early 2002, are continuing. A lengthy term can be expected. After all, the "Tokyo

${ }^{24}$ Skipper (2001) documents some examples of greater openness in financial services; Cowhey and Klimenko (2001) discuss the telecommunications agreement. 
Round" of GATT negotiations lasted 1973-1979, and the Uruguay Round lasted 1986-1994. The issues that are to be negotiated in the "GATS 2000 Round" will be at least as complex as those that occupied the earlier trade negotiation rounds.

There are at least four additional reasons to expect lengthy and difficult negotiations. First, as Hoekman and Messerlin (2000) point out, any detailed negotiations concerning trade in services inevitably will be more complicated than those that apply to trade in goods. Country negotiators invariably begin their "request-offer" trade negotiations from a mercantilist perspective: "My country wants your country to lower your trade barriers on the following items; in return (and only in return) we would be willing to lower our barriers on the same or other items." For trade in goods, the barriers are often in the form of tariffs, so that the bargaining as to reciprocal reductions can occur in terms of readily comparable numerical reductions. Even when the barriers are in the form of quotas, a tariff-equivalent measure can usually be computed.

As was described above, however, the barriers to international trade in services are rarely in the form of tariffs or simple quotas. Instead, the regulatory barriers for services are far more complex and subtle, requiring extensive efforts to distill the true pretective nature of the barriers, as well as the gains that could be achieved through their removal. ${ }^{25}$ The determination of what constitutes an acceptable quid pro quo in such circumstances, especially when the barriers surrounding different services are being requested and offered, will surely create an additional layer of bargaining frictions and delay.

Second, for federal countries such as the U.S., some of the regulatory impediments (e.g., banking, insurance, professional services) occur at the state level, yet it is the national negotiators who are engaged in the bargaining process. Again, this must add to bargaining frictions and delay.

Third, recall that the GATS schedules of country bindings consist of "positive lists" of those

\footnotetext{
${ }^{25}$ For examples of such efforts, see the essays in Findlay and Warren (2000).
} 
services sectors that a country has chosen to bind in some fashion to the GATS process. Though the bound sectors are thereby transparent and open to further negotiations with respect to any remaining barriers, the unbound sectors are simply unlisted and therefore opaque. This lack of transparency as to the unbound sectors will surely increase the difficulties of negotiations, since negotiators will have a less explicit knowledge base for their bargaining requests with respect to these opaque sectors.

Fourth, with only services "on the table" for negotiations, the room for maneuvering and bargaining will be restricted, since four-fifths of trade flows -- i.e., goods -- will nqt pe explicitly available for the reciprocal counteroffers that will be part of the bargaining process. ${ }^{26}$ Again, this will surely impede the negotiations.

5. A summing up. The negotiation process for trade in services has been, and will continue to be, tentative and slow. One indicator of this slow progress has been the absence of any major disputes in services trade that would require WTO adjudication. Countries are not yet seriously confronting each others' policies and impediments. The slow progress is probably the unavoidable reflection and consequence of the complexity and subtlety of services and their regulation and the national sensitivities that accompany this regulation, as is indicated by the "positive list" approach, the widespread exemptions, etc.

Unfortunately, the disruptions at the WTO "ministerial" meeting in Seattle in late 1999 have surely slowed the process yet further. The disruptions have thrown the WTO on the defensive and have made the WTO organization more tolerant of -- and even endorsing -- governments' protectionist tendencies and more tentative in its defense of freer trade in services. For example, in an April 2, 2001, WTO press release announcing the adoption of GATS negotiating guidelines and

\footnotetext{
${ }^{26}$ The four-fifths figure is an over-estimate, since a significant fraction of trade flows in goods is now unrestricted and thus unavailable for counteroffers. Also, there may be some implicit promises as to future concessions with respect to goods barriers that may be possible. Still, the unavailability of goods categories for bargaining will unavoidably restrict the bargaining process.
} 
procedures and the conclusion of an interim assessment of the negotiations, WTO Director-General Mike Moore was prominently quoted (in the third paragraph of the press release) as follows: "One significance of the guidelines should not go unnoticed... Governments have unequivocally endorsed some of the fundamental principles of the GATS: Governments' right to regulate and to introduce new regulations on the supply of services in pursuit of national policy objectives; their right to specify which services they wish to open to foreign suppliers and under which conditions; and the overarching principle of flexibility for developing and least-developed countries" (WTO 2001b).

Similarly, a GATS (2001c) publication, "GATS -- Fact and Fiction", repeatedly emphasizes what the GATS isn't, with the definite flavor of tolerance for protectionism:

"-- Member Governments choose those service sectors or subsectors on which they will make commitments guaranteeing the right of foreign suppliers to provide the service. Each Member must have a schedule of commitments, but there is no minimum requirement as to its coverage -- some cover only a small part of one sector;

"-- For those services that are committed, Governments may set limitations specifying the level of market access and the degree of national treatment they are prepared to guarantee;

"-- Governments were able to limit commitments to one or more of the four recognized 'modes of supply' through which services are traded. They may also withdraw and renegotiate commitments;

"-- In order to provide more favourable treatment to certain trading partners, Governments may take exemptions, in principle limited to 10 years' duration, from the MFN principle, which is otherwise applicable to all services, whether scheduled or not" (WTO 2001c pp. 6-7).

A page later in the same document, "There is no obligation on any WTO Member to allow foreign supply of any service..." (WTO 2001c p. 8)

All of these descriptions of negative features of the GATS are, of course, accurate; and they are duly accompanied by positive statements about the benefits and virtues of expanded trade and 
reduced barriers. Nevertheless, the prominence of these negative descriptions in WTO pronouncements and publications indicates a defensiveness that may well encourage the everpresent mercantilist/protectionist tendencies within member countries and thereby cause greater delays in the negotiations, greater rigidities in the bargaining, and lesser reductions in barriers in the outcomes.

Excessive pessimism is probably not warranted. The processes of international trade in services have surely benefited, and will continue to benefit, from the existence of the WTO and the GATS and the attention that has thereby been focused on both the existence of international trade in services and the existence of barriers that restrict that trade. The GATS 2000 negotiating round will surely -- eventually -- bring greater liberalization than existed before. ${ }^{27}$ But the cause of freer trade usually needs all of the help that it can get to withstand the forces of mercantilism and protectionism. Backsliding by the WTO, even for understandable tactical reasons, does not help.

${ }^{27}$ Forward-looking assessments of the GATS and recommendations for the future can be found in, e.g., Feketekuty (2000a, 2000b), Hoekman (2000), Hoekman and Messerlin (2000), Low and Mattoo (2000), Thompson (2000), and WTO (2001d). 


\section{Conclusion}

International trade in services is still a relatively new phenomenon: conceptually, statistically, and diplomatically. There is still much to be explored in all of these dimensions. It is likely that the early twenty-first century will see substantial progress in all of them. 


\section{References}

Aharoni, Yair, Changing Roles of State Intervention in Services in an Era of Open International Markets. Albany, N.Y.: State University Press of New York, 1997.

Aharoni, Yair and Lilach Nachum, Globalization of Services: Some Implications for Theory and Practice. London: Routledge, 2000.

Ascher, Bernard, "Trade Disciplines for Regulation: Lessons from the Accountancy Sector," paper delivered at the Conference on (R)Evolution of Quality and Competency Assurance in the Global Marketplace, Santa Fe, N.M., June 2-4, 1999. Washington, D.C.: USTR, draft 7/28/99, mimeo.

Altinger, Laura and Alice Enders, "The Scope and Depth of GATS Commitments," The World Economy, 19 (May 1996), pp. 307-332.

Baumol, William, "Macroeconomics of Unbalanced Growth: The Anatomy of Urban Crisis," American Economic Review, 57 (June 1967), pp. 415-426.

Beck, Thorsten, Asli Demirguc-Kunt, Ross Levine, and Vojislav Maksimovic, "Financial Structure and Economic Development: Firm, Industry, and Country Evidence," Policy Research Working Paper No. 2423, World Bank, Washington, D.C., June 14, 2000.

Borga, Maria and Michael A. Mann, "U.S. International Services: Cross-Border trade in 2000 and Sales Through Affiliates in 1999," Survey of Current Business 81 (November 2001), pp. 49-95.

Claessens, Stijn, Asli Demirguc-Kunt, and Harry Huizinga, "How Does Foreign Entry Affect the Domestic Banking Market?" in Stijn Claessens and Marion Jansen, eds., The Internationalization of Financial Services: Issues and Lessons for Developing Countries. The Hague: Kluwer Law International, 2000, ch. 6.

Colecchia, Alessandra, "Measuring Barriers to Market Access for Services: A Pilot Study on Accountancy Services, in Christopher Findlay and Tony Warren, eds., Impediments to Trade in Services: Measurement and Policy Implications. London: Routledge, 2000, pp. 245-266.

Cowhey, Peter F. and Mikhail M. Klimenko, "Implementing Telecommunications Liberalization in Developing Countries after the WTO Agreement on Basic Telecommunications Services," in Robert M. Stern, ed., Services in the International Economy. Ann Arbor: University of Michigan Press, 2001, pp. 349-368.

Deardorff, Alan V., "International Provision of Trade Services, Trade, and Fragmentation," Discussion Paper No. 463, Research Seminar in International Economics, School of Public Policy, University of Michigan, Ann Arbor, Mich., August 30, 2000. 
Evenett, Simon J. and Bernard M. Hoekman, "Government Procurement of Services and Multilateral Disciplines," in Pierre Sauve and Robert M. Stern, eds., GATS 2000: New Directions in Services Trade Liberalization. Washington, D.C.: Brookings Institution, 2000, pp. 143-164.

Feketekuty, Geza, "Assessing and Improving the Architecture of GATS," in Pierre Sauve and Robert M. Stern, eds., GATS 2000: New Directions in Services Trade Liberalization. Washington, D.C.: Brookings Institution, 2000a, pp. 85-111.

Feketekuty, Geza, Improving the Architecture of the General Agreement on Trade in Services," in Sherry M. Stephenson, ed., Services in the Western Hemisphere: Liberalization, Integration, and Reform. Washington, D.C.: Brookings Institution, 2000b, pp. 19-42.

Findlay, Christopher and Tony Warren, eds., Impediments to Trade in Services: Measurement and Policy Implications. London: Routledge, 2000.

Fox, Nancy Ruth and Lawrence J. White, "U.S. Ocean Shipping Policy: Going against the Tide," Annals of the American Academy of Political and Social Science, 553 (September 1997), pp. 7586.

Gruenspecht, Howard K, and Lester B. Lave, "The Economics of Health, Safety, and Environmental Regulation," in Richard Schmalensee and Robert D. Willig, eds., Handbook of Industrial Organization, vol 2. Amsterdam: North Holland, 1989, pp. 1507-1550.

Hoekman, Bernard M., "Towards a More Balanced and Comprehensive Services Agreement," in Jeffrey J. Schott, ed., The WTO after Seattle. Washington, D.C.: Institute for International Economics, July 2000, pp. 119-135.

Hoekman, Bernard M. and Carlos A. Primo Braga, "Protection and Trade in Services: A Survey," in Open Economies Review, 8 (July 1997), pp. 285-308.

Hoekman, Bernard M. and Patrick A. Messerlin, "Liberalizing Trade in Services: Reciprocal Negotiations and Regulatory Reform," in Pierre Sauve and Robert M. Stern, eds., GATS 2000: New Directions in Services Trade Liberalization. Washington, D.C.: Brookings Institution, 2000, pp. 487-508.

Holmes, Leanne and Alexis Hardin, "Assessing Barriers to Services Sector Investment," in Christopher Findlay and Tony Warren, eds., Impediments to Trade in Services: Measurement and Policy Implications. London: Routledge, 2000, pp. 52-70.

Joskow, Paul L. and Roger G. Noll, "Economic Regulation: Deregulation and Regulatory Reform during the 1980s," in Martin Feldstein, ed., American Economic Policy in the 1980s. Chicago: University of Chicago Press, 1994, pp. 367-440. 
Joskow, Paul L. and Nancy L. Rose, "The Effects of Economic Regulation," in Richard Schmalensee and Robert D. Willig, eds., Handbook of Industrial Organization, vol. 2. Amsterdam: North Holland, 1989, pp. 1449-1506.

Kang, Jong-Soon, "Price Impact of Restrictions on Maritime Transport Services," in Christopher Findlay and Tony Warren, eds., Impediments to Trade in Services: Measurement and Policy Implications. London: Routledge, 2000a, pp. 189-200.

Kang, Jong-Soon, "The Services Sector in Output and in International Trade," in Christopher Findlay and Tony Warren, eds., Impediments to Trade in Services: Measurement and Policy Implications. London: Routledge, 2000b, pp. 18-41.

Kang, Jong-Soon and Christopher Findlay, "Regulatory Reform in the Maritime Industry," in Christopher Findlay and Tony Warren, eds., Impediments to Trade in Services: Measurement and Policy Implications. London: Routledge, 2000, pp. 152-171.

Kasper, Daniel M., Deregulation and Globalization: Liberalizing International Trade in Air Services. Cambridge, Mass.: Ballinger, 1988.

King Robert G. and Ross Levine, "Finance and Growth: Schumpeter Might Be Right," Quarterly Journal of Economics, 108 (August 1993a), pp. 717-737.

King, Robert G. and Ross Levine, "Finance, Entrepreneurship, and Growth: Theory and Evidence," Journal of Monetary Economics, 32 (December 1993b), pp. 513-542.

La Porta, Rafael, Florencio Lopez-de-Silanes, Andre Schleifer, and Robert W. Vishny, "Legal Determinants of External Finance," Journal of Finance, 52 (July 1997), pp. 1131-50.

La Porta, Rafael, Florencio Lopez-de-Silanes, Andre Schleifer, and Robert W. Vishny, "Law and Finance," Journal of Political Economy, 106 (December 1998), pp. 1133-1155.

Landefeld, J. Steven and Kan H. Young, "U.S. Trade in Services: 1970-1985," in Wray O. Candilis, ed., United States Service Industries Handbook. New York: Praeger, 1988, pp. 91-126.

Levine, Ross, "Foreign Banks, Financial Development, and Economic Growth," in Claude Barfield, ed., International Financial Markets: Harmonization versus Competition. Washington: American Enterprise Institute, 1996, pp. 224-254.

Levine, Ross, "Financial Development and Economic Growth: Views and Agenda," Journal of Economic Literature, 35 (June 1997), pp. 688-726.

Levine, Ross, "The Legal Environment, Banks, and Long-Run Economic Growth, Journal of 
Money, Credit and Banking, (August 1998), pp. 596-613.

Levine, Ross, "Law, Finance, and Economic Growth," Journal of Financial Intermediation, 8 (January/April 1999), pp. 8-35.

Levine, Ross and Sara Zervos, "Stock Markets, Banks, and Economic Growth," American Economic Review, 88 (June 1998), pp. 537-558.

Low, Patrick and Aaditya Mattoo, "Is There a Better Way? Alternative Approaches to Liberalization under GATS," in Pierre Sauve and Robert M. Stern, eds., GATS 2000: New Directions in Services Trade Liberalization. Washington, D.C.: Brookings Institution, 2000, pp. 449-472.

McGuire, Greg and Michael Schuele, "Restrictiveness of International Trade in Banking Services," in Telecommunications Services," in Christopher Findlay and Tony Warren, eds., Impediments to Trade in Services: Measurement and Policy Implications. London: Routledge, 2000, pp. 201-214.

McGuire, Greg, Michael Schuele, and Tina Smith, "Restrictiveness of International Trade in Maritime Services," in Telecommunications Services," in Christopher Findlay and Tony Warren, eds., Impediments to Trade in Services: Measurement and Policy Implications. London: Routledge, 2000, pp. 172-188.

Nicolaidis, Kalypso, "Learning while Doing: How Services Got on the Uruguay Round Agenda," in Albert Bressand and Kalypso Nicolaidis, eds., Strategic Trends in services: An Inquiry into the Global Service Economy. New York: Ballinger, 1989, pp. 161-179.

Noll, Roger G., "Economic Perspectives on the Politics of Regulation," in Richard Schmalensee and Robert D. Willig, eds., Handbook of Industrial Organization, vol. 2. Amsterdam: North Holland, 1989, pp. 1253-1287.

Pugel, Thomas G. and Peter H. Lindert, International Economics, 11th edn. New York: McGrawHill, 2000.

Rajan, Raghuram H. and Luigi Zingales, "Financial Dependence and Growth," American Economic Review, 88 (June 1998), pp. 559-586.

Sauve, Pierre and Robert M. Stern, eds., GATS 2000: New Directions in Services Trade Liberalization. Washington, D.C.: Brookings Institution, 2000.

Skipper, Harold D., Jr., Insurance in the General Agreement on Trade in Services. Washington, D.C.: AEI Press, 2001.

Stephenson, Sherry M., ed., Services in the Western Hemisphere: Liberalization, Integration, and 
Reform. Washington, D.C.: Brookings Institution, 2000.

Stern, Robert M., ed., Services in the International Economy. Ann Arbor: University of Michigan Press, 2001.

Thompson, Rachel, "Formula Approaches to Improving GATS Commitments," in Pierre Sauve and Robert M. Stern, eds., GATS 2000: New Directions in Services Trade Liberalization. Washington, D.C.: Brookings Institution, 2000, pp. 473-486.

U.S. International Trade Commission, General Agreement on Trade in Services: Examination of the Schedules of Commitments Submitted by Eastern Europe, the European Free Trade Association, and Turkey. Publication 3127, September 1998.

U.S. International Trade Commission, General Agreement on Trade in Services (GATS): Examination of Asia/Pacific Trading Partners' Schedules of Commitments. Publication 3053, August 1997.

U.S. International Trade Commission, General Agreement on Trade in Services (GATS): Examination of Major Trading Partners' Schedules of Commitments. Publication 2940, January 1996a.

U.S. International Trade Commission, General Agreement on Trade in Services (GATS): Examination of South American Trading Partners' Schedules of Commitments. Publication 3007, December 1996b.

U.S. International Trade Commission, Recent Trends in U.S. Services Trade: 2001 Annual Report. Publication 3409, May 2001.

Warren, Tony, "The Impact on Output of Impediments to Trade and Investment" in Telecommunications Services," in Christopher Findlay and Tony Warren, eds., Impediments to Trade in Services: Measurement and Policy Implications. London: Routledge, 2000a, pp. 85-100.

Warren, Tony, "The Identification of Impediments to Trade and Investment in Telecommunications Services," in Christopher Findlay and Tony Warren, eds., Impediments to Trade in Services: Measurement and Policy Implications. London: Routledge, 2000b, pp. 71-84.

Warren, Tony and Christopher Findlay, "Measuring Impediments to Trade in Services," in Pierre Sauve and Robert M. Stern, eds., GATS 2000: New Directions in Services Trade Liberalization. Washington, D.C.: Brookings Institution, 2000, pp. 57-84.

White, Lawrence J., International Trade in Ocean Shipping Services: The U.S. and the World. Cambridge, Mass.: Ballinger, 1988. 
White, Lawrence J., "Competition versus Harmonization: An Overview of International Regulation of Financial Services," in Claude Barfield, ed., International Trade in Financial Services. Washington: American Enterprise Institute, 1996, pp. 5-48.

White, Lawrence J., Reducing the Barriers to International Trade in Accounting Services. Washington, D.C.: AEI Press, 2001.

White, Lawrence J., "Unilateral trade Openness: The Experience of the U.S. Financial Services Sector," in Jagdish Bhagwati, ed., Unilateral Trade Liberalization. Cambridge, Mass.: MIT Press, 2002 (forthcoming).

World Trade Organization, Council for Trade in Services, "Accountancy Services," December 4, 1998.

World Trade Organization, Council for Trade in Services, "Structure of Commitments for Modes 1, 2, and 3," March 3, 1999a.

World Trade Organization, Secretariat, Trade in Services Division, "An Introduction to the GATS," October 1999b.

World Trade Organization, International Trade Statistics 2001. Geneva: World Trade Organization, 2001a.

World Trade Organization, "WTO Services Talks Press Ahead," Press Release, April 2, $2001 \mathrm{~b}$.

World Trade Organization, "GATS -- Fact and Fiction," 2001c.

World Trade Organization, Guide to the GATS: An Overview of Issues for Further Trade Liberalization in Services. The Hague: Kluwer Law International, 2001d.

Yarbrough, Beth V. and Robert M. Yarbrough, The World Economy: Trade and Finance, 4th edn. New York: Dryden Press, 1997. 
Table 1: Total World Trade, 1980-2000

\begin{tabular}{|l|c||c|c|c|}
\hline & Year & \multicolumn{3}{c|}{ Average Annual \% Change } \\
\hline & 2000 & $1980-2000$ & $1980-1990$ & $1990-2000$ \\
\hline & & & & $5.26 \%$ \\
\hline Value of goods (\$B) & $\$ 6,186$ & $5.73 \%$ & 7.92 & $6.20 \%$ \\
\hline Value of services (\$B) & $\$ 1,435$ & 7.08 & & \\
\hline Services as a \% of total trade & $18.83 \%$ & & 3.25 & 2.26 \\
\hline Real GDP & & 2.73 & 3.93 & 6.96 \\
\hline
\end{tabular}

Sources: WTO (2001a), and data tables found at 
Table 2: World Trade, by Regions, 1980-2000

\begin{tabular}{|c|c|c|c|c|}
\hline & Year & \multicolumn{3}{|c|}{ Average Annual \% Change } \\
\hline & 2000 & $1980-2000$ & 1980-1990 & $1990-2000$ \\
\hline \multicolumn{5}{|l|}{ North America $^{\mathrm{a}}$} \\
\hline \multicolumn{2}{|l|}{ Goods exports (val.) } & $6.62 \%$ & $5.92 \%$ & $7.33 \%$ \\
\hline \multicolumn{2}{|l|}{ Services exports (val.) } & 10.14 & 12.83 & 7.51 \\
\hline Services as a $\%$ of total exports & $22.8 \%$ & & & \\
\hline \multicolumn{2}{|l|}{ Goods imports (val.) } & 8.04 & 7.19 & 8.89 \\
\hline \multicolumn{2}{|l|}{ Services imports (val.) } & 9.53 & 12.39 & 6.74 \\
\hline Services as a $\%$ of total imports & $14.1 \%$ & & & \\
\hline \multicolumn{5}{|l|}{ Latin America \& Caribbean } \\
\hline \multicolumn{2}{|l|}{ Goods exports (val.) } & 6.10 & 2.95 & 9.35 \\
\hline \multicolumn{2}{|l|}{ Services exports (val.) } & 6.42 & 5.43 & 7.41 \\
\hline Services as a $\%$ of total exports & $14.0 \%$ & & & \\
\hline \multicolumn{2}{|l|}{ Goods imports (val.) } & 5.90 & 0.55 & 11.54 \\
\hline \multicolumn{2}{|l|}{ Services imports (val.) } & 4.71 & 1.99 & 7.51 \\
\hline Services as a $\%$ of total imports & $15.9 \%$ & & & \\
\hline \multicolumn{5}{|l|}{ Western Europe } \\
\hline \multicolumn{2}{|l|}{ Goods exports (val.) } & 5.64 & 7.23 & 4.08 \\
\hline \multicolumn{2}{|l|}{ Services exports (val.) } & 5.72 & 6.93 & 4.53 \\
\hline Services as a $\%$ of total exports & $21.2 \%$ & & & \\
\hline \multicolumn{2}{|l|}{ Goods imports (val.) } & 5.23 & 6.27 & 4.20 \\
\hline \multicolumn{2}{|l|}{ Services imports (val.) } & 6.07 & 7.56 & 4.61 \\
\hline Services as a $\%$ of total imports & $20.6 \%$ & & & \\
\hline \multicolumn{5}{|l|}{ Africa } \\
\hline \multicolumn{2}{|l|}{ Goods exports (val.) } & 0.91 & -1.48 & 3.35 \\
\hline \multicolumn{2}{|l|}{ Services exports (val.) } & 4.48 & 4.00 & 4.96 \\
\hline Services as a $\%$ of total exports & $18.5 \%$ & & & \\
\hline \multicolumn{2}{|l|}{ Goods imports (val.) } & 1.75 & -0.20 & 3.74 \\
\hline \multicolumn{2}{|l|}{ Services imports (val.) } & 1.67 & -0.26 & 3.64 \\
\hline Services as a \% of total imports & $23.2 \%$ & & & \\
\hline \multicolumn{5}{|l|}{ Asia } \\
\hline \multicolumn{2}{|l|}{ Goods exports (val.) } & 9.04 & 9.37 & 8.72 \\
\hline \multicolumn{2}{|l|}{ Services exports (val.) } & 9.41 & 10.13 & 8.70 \\
\hline Services as a \% of total exports & $14.3 \%$ & & & \\
\hline \multicolumn{2}{|l|}{ Goods imports (val.) } & 8.08 & 8.41 & 8.10 \\
\hline \multirow{2}{*}{\multicolumn{2}{|c|}{ Services imports (val.) }} & 8.62 & 9.85 & 7.40 \\
\hline & $18.7 \%$ & & & \\
\hline
\end{tabular}

${ }^{\mathrm{a}}$ U.S. and Canada only

Sources: WTO (2001a), and data found at 
Table 3: Ten Leading Country Exporters and Importers of Goods and Services, 2000

\begin{tabular}{|c|c|c|c|c|c|c|c|}
\hline \begin{tabular}{|l} 
Goods \\
Exports
\end{tabular} & $\begin{array}{l}\text { Value } \\
(\$ B)\end{array}$ & $\begin{array}{l}\text { Services } \\
\text { Exports }\end{array}$ & $\begin{array}{l}\text { Value } \\
(\$ B)\end{array}$ & $\begin{array}{l}\text { Goods } \\
\text { Imports } \\
\end{array}$ & $\begin{array}{l}\text { Value } \\
(\$ B)\end{array}$ & $\begin{array}{l}\text { Services } \\
\text { Imports }\end{array}$ & $\begin{array}{l}\text { Value } \\
\text { (\$B) }\end{array}$ \\
\hline 1. U.S. & $\$ 781.1$ & U.S. & $\$ 274.6$ & U.S. & $\$ 1,257.6$ & U.S. & $\$ 198.9$ \\
\hline 2. Germany & 551.5 & U.K. & 99.9 & Germany & 502.8 & Germany & 132.3 \\
\hline 3. Japan & 479.2 & France & 81.2 & Japan & 379.5 & Japan & 115.7 \\
\hline 4. France & 298.1 & Germany & 80.0 & U.K. & 337.0 & U.K & 82.1 \\
\hline 5. U.K. & 284.1 & Japan & 68.3 & France & 305.4 & France & 61.5 \\
\hline 6. Canada & 276.6 & Italy & 56.7 & Canada & 244.8 & Italy & 55.7 \\
\hline 7. China & 249.3 & Spain & 53.0 & Italy & 236.5 & $\begin{array}{l}\text { Netherland } \\
\text { s }\end{array}$ & 51.1 \\
\hline 8. Italy & 237.8 & $\begin{array}{l}\text { Netherland } \\
\text { s }\end{array}$ & 52.3 & China & 225.1 & Canada & 41.9 \\
\hline 9. Netherlands & 212.5 & Hong Kong & 42.1 & Hong Kong & 214.2 & Belg.-Lux. & 38.3 \\
\hline 10. Hong Kong & 202.4 & Belg.-Lux. & 42.0 & $\begin{array}{l}\text { Netherland } \\
\text { s }\end{array}$ & 198.0 & China & 35.9 \\
\hline $\begin{array}{l}\text { Leading } 10 \text { as a } \\
\% \text { of world } \\
\text { total }\end{array}$ & $56.14 \%$ & & $59.24 \%$ & & $58.49 \%$ & & $56.68 \%$ \\
\hline
\end{tabular}

Source: WTO (2001a) 
Table 4: Major Categories of World Trade in Services

and Ten Leading Country Exporters and Importers for Those Categories, 2000

\begin{tabular}{|c|c|c|c|}
\hline Exporters & Value $(\$ B)$ & Importers & Value (\$B) \\
\hline \multicolumn{4}{|c|}{ A. Transportation Services; World Total $=\$ 330 B$} \\
\hline 1. U.S. & $\$ 51.2$ & 1. U.S. & $\$ 64.6$ \\
\hline 2. Japan & 25.6 & 2. Japan & 35.1 \\
\hline 3. Netherlands & 20.8 & 3. Germany & 25.0 \\
\hline 4. Germany & 19.4 & 4. U.K. & 22.0 \\
\hline 5. France & 19.4 & 5. France & 19.5 \\
\hline 6. U.K. & 18.2 & 6. Netherlands & 14.6 \\
\hline 7. Hong Kong & 13.7 & 7. Italy & 13.7 \\
\hline 8. S. Korea & 12.8 & 8. S. Korea & 11.0 \\
\hline 9. Denmark & 11.0 & 9. China & 10.4 \\
\hline 10. Belg.-Lux. & 10.4 & 10. Denmark & 9.4 \\
\hline $\begin{array}{l}\text { Leading } 10 \text { as a } \\
\% \text { of world total }\end{array}$ & $61.36 \%$ & $\begin{array}{l}\text { Leading } 10 \text { as a } \\
\% \text { of world total }\end{array}$ & $68.27 \%$ \\
\hline \multicolumn{4}{|c|}{ B. Travel Services; World Total $=\$ 465 \mathrm{~B}$} \\
\hline 1. U.S. & $\$ 100.5$ & 1. U.S. & $\$ 67.3$ \\
\hline 2. Spain & 30.9 & 2. Germany & 47.1 \\
\hline 3. France & 30.9 & 3. U.K. & 38.0 \\
\hline 4. Italy & 27.4 & 4. Japan & 31.9 \\
\hline 5. U.K. & 21.7 & 5. France & 17.9 \\
\hline 6. Germany & 17.6 & 6. Italy & 15.4 \\
\hline 7. China & 16.2 & 7. China & 13.1 \\
\hline 8. Canada & 10.6 & 8. Hong Kong & 12.5 \\
\hline 9. Austria & 10.0 & 9. Netherlands & 12.2 \\
\hline 10. Australia & 8.4 & 10. Canada & 12.1 \\
\hline $\begin{array}{l}\text { Leading } 10 \text { as a } \\
\% \text { of world total }\end{array}$ & $58.97 \%$ & $\begin{array}{l}\text { Leading } 10 \text { as a } \\
\% \text { of world total }\end{array}$ & $57.53 \%$ \\
\hline \multicolumn{4}{|c|}{ C. Other Services; World Total $=\$ 640 \mathrm{~B}$} \\
\hline 1.U.S. & $\$ 122.9$ & 1. U.S. & $\$ 67.0$ \\
\hline 2.U.K. & 60.0 & 2. Germany & 60.2 \\
\hline 3. Germany & 43.0 & 3. Japan & 48.7 \\
\hline 4. Japan & 39.3 & 4. Italy & 26.6 \\
\hline 5. France & 30.8 & 5. Netherlands & 24.3 \\
\hline 6. Netherlands & 24.4 & 6. France & 24.1 \\
\hline 7. Belg.-Lux. & 24.2 & 7. Ireland & 23.5 \\
\hline 8. Hong Kong & 20.9 & 8. U.K. & 22.1 \\
\hline 9. Italy & 20.4 & 9. Canada & 20.4 \\
\hline 10. Canada & 19.4 & 10. Belg.-Lux. & 19.8 \\
\hline $\begin{array}{l}\text { Leading } 10 \text { as a } \\
\% \text { of world total }\end{array}$ & $63.33 \%$ & $\begin{array}{l}\text { Leading } 10 \text { as a } \\
\% \text { of world total }\end{array}$ & $52.61 \%$ \\
\hline
\end{tabular}

Source: WTO (2001a) 
Table 5: U.S. Trade in Services, 1990-2000

\begin{tabular}{|l|c|c|c|c|}
\hline & \multicolumn{2}{|c|}{ Exports } & \multicolumn{2}{c|}{ Imports } \\
\hline & $\begin{array}{c}\text { Value in } \\
2000(\$ \mathrm{~B})\end{array}$ & $\begin{array}{c}\text { Avg. Ann. \% Ch. } \\
1990-2000\end{array}$ & $\begin{array}{c}\text { Value in } \\
2000(\$ \mathrm{~B})\end{array}$ & $\begin{array}{c}\text { Avg. Ann \% Ch. } \\
1990-2000\end{array}$ \\
\hline & & & & \\
\hline Travel & $\$ 82.0$ & $6.67 \%$ & $\$ 64.5$ & $5.62 \%$ \\
\hline Passenger fares & 20.7 & 3.09 & 24.2 & 8.67 \\
\hline Other transportation & 30.2 & 3.19 & 41.1 & 5.10 \\
\hline Royalties \& license fees & 38.0 & 8.62 & 16.1 & 17.78 \\
\hline Services to affiliates & 31.6 & 8.79 & 25.3 & 10.75 \\
\hline Education & 10.3 & 7.21 & 2.1 & 12.52 \\
\hline Financial services & 17.0 & 14.46 & 4.5 & 6.12 \\
\hline Insurance, net & 2.4 & 26.49 & 9.2 & 17.01 \\
\hline Telecommunications & 3.8 & 3.46 & 5.4 & -0.41 \\
\hline Computer \& data processing ser. & 2.5 & 9.10 & 0.8 & 34.25 \\
\hline Constr., eng., arch. \& mining ser. & 5.3 & 19.74 & 0.4 & 9.52 \\
\hline Data base and other info. ser. & 2.5 & 23.99 & 0.2 & 14.16 \\
\hline Industrial engineering services & 1.6 & 13.16 & 0.3 & 14.87 \\
\hline Install., maint., \& repair of equip. & 4.2 & 7.52 & 0.4 & -5.10 \\
\hline Legal services & 3.2 & 21.70 & 0.8 & 22.42 \\
\hline Mgt. consult. \& p.r. services & 1.8 & 17.88 & 0.7 & 18.02 \\
\hline Medical services & 1.4 & 8.55 & n.a. & n.a. \\
\hline Operational leasing & 2.7 & 12.98 & 0.2 & -1.87 \\
\hline R\&D \& testing services & 1.0 & 9.91 & 0.9 & 15.02 \\
\hline Misc. disbursements & 0.1 & $2.59^{\text {a }}$ & 1.1 & $12.22^{\text {a }}$ \\
\hline Other services & 16.3 & 8.98 & 2.4 & 11.61 \\
\hline Total & $\mathbf{\$ 2 7 8 . 6}$ & $\mathbf{7 . 3 4 \%}$ & $\mathbf{\$ 2 0 0 . 6}$ & $\mathbf{7 . 4 0 \%}$ \\
\hline
\end{tabular}

${ }^{\text {a }}$ For years 1991-2000.

${ }^{\mathrm{b}}$ Includes accounting, auditing, bookkeeping, advertising, mailing, reproduction, commercial art, personnel supply, sports and performing arts, training, film and tape rentals, etc.

Source: Borga and Mann (2001) 
Table 6: Sales of Services through Nonbank Majority-Owned Affiliates, 1999

\begin{tabular}{|l|c|c|}
\hline Industry Category of Affiliate & $\begin{array}{c}\text { Sales by U.S.-Owned Affiliates } \\
\text { Abroad (\$B) }\end{array}$ & $\begin{array}{c}\text { Sales by Foreign-Owned } \\
\text { Affiliates in the U.S. (\$B) }\end{array}$ \\
\hline Manufacturing & $\$ 13.0$ & $\$ 27.8$ \\
\hline Wholesale trade & 12.1 & 12.6 \\
\hline Retail trade & 0.5 & 0.4 \\
\hline Publishing industries & 11.7 & 14.9 \\
\hline $\begin{array}{l}\text { Motion picture \& sound } \\
\text { recording industries }\end{array}$ & 8.2 & 19.3 \\
\hline $\begin{array}{l}\text { Broadcasting \& } \\
\text { telecommunications }\end{array}$ & 25.3 & 3.3 \\
\hline $\begin{array}{l}\text { Information \& data processing } \\
\text { services }\end{array}$ & 14.1 & 15.3 \\
\hline $\begin{array}{l}\text { Finance, except depositary } \\
\text { institutions }\end{array}$ & 31.6 & 78.8 \\
\hline Insurance & 46.9 & 17.7 \\
\hline Real estate \& rental \& leasing & 10.1 & 4.0 \\
\hline $\begin{array}{l}\text { Computer systems design \& } \\
\text { related services }\end{array}$ & 27.2 & 11.0 \\
\hline $\begin{array}{l}\text { Other professional, scientific, \& } \\
\text { technical services }\end{array}$ & 32.0 & 19.0 \\
\hline Utilities & 34.2 & 18.8 \\
\hline Transportation \& warehousing & 16.6 & 13.6 \\
\hline $\begin{array}{l}\text { Administration support \& waste } \\
\text { management }\end{array}$ & 21.0 & $\mathbf{\$ 2 8 9 . 3}$ \\
\hline Accommodation \& food services & 16.0 & 13.3 \\
\hline Other industries & $\mathbf{3 3 8 . 4}$ & \\
\hline \multicolumn{1}{|c|}{ Total } & & \\
\hline
\end{tabular}

Source: Borga and Mann (2001) 
Table 7: Aggregate Sales of Services through Nonbank Majority-Owned Affiliates, 1986-1999

\begin{tabular}{|l|c|c|}
\hline Year & $\begin{array}{c}\text { Sales by U.S.-Owned Affiliates } \\
\text { Abroad }(\$ B)\end{array}$ & $\begin{array}{c}\text { Sales by Foreign-Owned } \\
\text { Affiliates in the U.S. (\$B) }\end{array}$ \\
\hline 1986 & $\$ 60.5$ & n.a. \\
\hline 1987 & 72.3 & $\$ 62.6$ \\
\hline 1988 & 83.8 & 73.2 \\
\hline 1989 & 99.2 & 94.2 \\
\hline 1990 & 121.3 & 109.2 \\
\hline 1991 & 131.6 & 119.5 \\
\hline 1992 & 140.6 & 128.0 \\
\hline 1994 & 142.6 & 134.7 \\
\hline 1995 & 159.1 & 145.4 \\
\hline 1996 & 190.1 & 149.7 \\
\hline 1997 & 223.2 & 168.4 \\
\hline 1998 & 255.3 & $223.1^{\text {a }}$ \\
\hline 1999 & 286.1 & 245.5 \\
\hline
\end{tabular}

${ }^{a}$ Major redefinition of sales of services through affiliates Source: Borga and Mann (2001) 